\title{
Angewandte Linguistik anwenden
}

Im Flugzeug wie im Spital, in der Wirtschaft wiein den Medien sind wir darauf angewiesen, dass Kommunikation funktioniert. Wo wir uns verständigen können, wird die Welt ein gutes Stück vorherseh- und steuerbar. Missverständnisse dagegen, Unverständnis und Nichtkommunikation erschweren oder verunmöglichen gemeinsames Wirken. So erstaunt wenig, dass erfolgreiche Kommunikation als Schlüsselfaktor einer immer dichter vernetzten Welt gilt (z. B. Ruben \& Gigliotti, 2017). Wie aber kann Kommunikation gelingen? Wie weiss man, was auf welche Art wirkt? Und wer muss was tun, damit com-municare, das Gemeinsam-Machen von Bedeutungsvorstellungen, glückt?

Mit entsprechenden Fragen rund um Kommunikation, Sprache, Verstehen und Verständigung befasst sich Angewandte Linguistik. Genauer gesagt sucht Angewandte Linguistik nach sprachlichen Mustern bei sozialen Gegebenheiten, nach Lösungen für gesellschaftlich bedeutsame Probleme, in denen Sprache eine tragende Rolle spielt. Dazu zählt die Verständigung innerhalb sozialer Gruppen, über gesellschaftliche Grenzen hinweg, etwa zwischen Alten und Jungen, Reichen und Armen, Laien und Expertinnen, sowie zwischen Politik, Gesellschaft und Wissenschaft. Und dazu zählt selbstverständlich auch die Kommunikation zwischen Sprachräumen und -kulturen.

Die Antworten aus unserem Fach helfen in der Praxis, Sprache effizient und zielführend einzusetzen und damit Kommunikation zu gestalten. Angewandte Linguistik ist ausgerichtet auf die Praxis. Sie forscht für die Praxis, über die Praxis und mit der Praxis (vgl. Cameron, Frazer, Rampton, \& Richardson, 1992: 22). Und sie vermittelt das so gewonnene Wissen zwischen allen Anspruchsgruppen: der beforschten Praxis, der Wissenschaft und der ganzen Gesellschaft. Soweit der Anspruch des Fachs an sich selbst. Was es bedeuten kann, diesen Anspruch umzusetzen in Forschung, Beratung und Lehre, das zeigen wir in diesem Band.

Als Beispiel dient das Departement Angewandte Linguistik der ZHAW Zürcher Hochschule für Angewandte Wissenschaften. Es ist eine der wenigen Hochschuleinheiten auf Stufe Departement/Fakultät in Europa, das sich umfassend der Angewandten Linguistik verpflichtet, mit 16 Professuren und über zweihundert Mitarbeitenden. Der Mehrwert des gemeinsamen Zugangs zu gesellschaftlichen Fragen zeigt sich in der grossen Vielfalt und aktiven Bearbeitung aktueller Herausforderungen von Sprache und Kommunikation in Beruf und Gesellschaft. Eben dieser Mehrwert soll hier deutlich werden.

Mit diesem Band danken wir unserem Kollegen Urs Willi, der das Departement und seine Vorstufe über drei Jahrzehnte geleitet und geprägt hat. Zu Wort kommen Forschende und Lehrende, deren Arbeit das Departement seit langem 
oder kurzem ausmacht. Der Band lädt ein, sich einen Überblick des Erreichten zu verschaffen, und zeigt am praktischen Beispiel, wie Facetten des Fachs ineinanderspielen, einander ergänzen und das Ganze zu mehr machen als zur Summe seiner Teile: zu einem Gewinn für die Verständigung in Wissenschaft und Hochschule, in Sprach- und Kommunikationsberufen - und in Alltag, Berufswelt und Öffentlichkeit überhaupt.

Ulla Kleinberger, Daniel Perrin, Gianni De Nardi und Marlies Whitehouse, Juni 2017

Cameron, D., Frazer, E., Rampton, B. \& Richardson, K. (1992). Researching language. Issues of power and method. London: Routledge.

Ruben, B. D. \& Gigliotti, R. A. (2017). Communication. Sine qua non of organizational leadership theory and practice. International Journal of Business Communication, 54(1), 12-30. 


\section{Doing Applied Linguistics}

Whether on an aircraft, at the hospital, in business or in the media, we rely on communication to work. Wherever we communicate successfully, we are able to make the world a considerably more predictable and manageable place. Misunderstandings and a lack of comprehension and communication, on the other hand, make fruitful collaboration complicated or even impossible. It is hardly surprising, therefore, that successful communication is the key factor in an increasingly interconnected world (e. g. Ruben \& Gigliotti, 2017). But how does communication succeed? How do we know what works and how it works? And who has to act to ensure that successful communication takes place and common goals can be achieved?

Such questions are the focus of Applied Linguistics, exploring issues related to communication, language, understanding and comprehension. More specifically, Applied Linguistics searches for linguistic patterns in successful social situations and for solutions to important societal problems in which language plays a significant role. This includes common understanding within social groups and across social boundaries, for example, between the old and the young, the rich and the poor, laypeople and experts, and between politics, society and science. And, of course, communication between language regions and cultures is also of interest in Applied Linguistics.

The findings from research in Applied Linguistics help us to use language efficiently and purposefully, and thus to make communication meaningful. Applied Linguistics is practice-oriented, with research that has implications for practice, conducted by and with practitioners (Cameron, Frazer, Rampton, \& Richardson, 1992, 22). The knowledge gained through this research is then disseminated to all stakeholders, including the practitioners investigated, theory and research as well as the whole of society at large. As for the aspirations and goals of the discipline itself, we show in this volume how these are realised in research, in consultancy and in teaching.

The School of Applied Linguistics at the Zurich University of Applied Sciences serves as an example of this. With 16 professorships and over 200 employees, it is one of the few university departments at the level of School / Faculty in Europe which is fully committed to Applied Linguistics. The added value of shared and collaborative approaches to social issues and problems is reflected in the great diversity and purposeful handling of current challenges, and this added value is illustrated in this volume.

We have compiled this volume to thank our colleague, Urs Willi, who has led and shaped the School in its current and in its previous form over the last three 
decades. There are contributions from researchers and teachers, some of whom are recent additions to the ZHAW and others who have worked in the School of Applied Linguistics for a long time. The volume provides an overview of what has been achieved, and uses practical examples to show how individual facets of the subject matter are intertwined, complementing each other and making the whole enterprise more than the sum of its parts. This leads to gains in knowledge and understanding in science and academia, in professions concerned with language and communication as well as in everyday life, the professional world and for society at large.

Ulla Kleinberger, Daniel Perrin, Gianni De Nardi, Marlies Whitehouse, and Richard Bale (translator), June 2017

Cameron, D., Frazer, E., Rampton, B. \& Richardson, K. (1992). Researching language. Issues of power and method. London: Routledge.

Ruben, B. D. \& Gigliotti, R. A. (2017). Communication. Sine qua non of organizational leadership theory and practice. International Journal of Business Communication, 54(1), 12-30. 


\section{S'appliquer à la linguistique appliquée}

Transports, milieu hospitalier, économie ou encore médias : autant d'exemples dans lesquels la communication joue un rôle primordial. Un échange fluide crée une plus grande visibilité et une plus grande aisance de manœuvre. À l'inverse, malentendus, incompréhension et non-communication rendent toute action commune difficile, voire impossible. Conséquence logique : la communication occupe une place toujours plus importante dans un monde toujours plus connecté (cf. Ruben \& Gigliotti, 2017). Dès lors, plusieurs questions se posent. Comment assurer une communication efficace? Comment connaître l'impact de telle mesure? Que faire pour que com-municare, la mise en commun du signifié, donne du sens?

La linguistique appliquée questionne la communication, la langue, la compréhension et l'échange. Plus spécifiquement, la linguistique appliquée recherche des schémas linguistiques dans les interactions sociales fertiles et des solutions aux problèmes sociétaux majeurs dans lesquels la langue joue un rôle important. Dans cette mission, elle s'intéresse aux échanges au sein des groupes sociaux, entre jeunes et vieux, pauvres et riches, experts et non-initiés et entre la politique, la société et la science. Sans oublier, bien sûr, la communication entre les régions linguistiques et culturelles.

Les réponses apportées par notre discipline permettent une utilisation efficace et ciblée de la langue et, partant, une approche pertinente de la communication. La linguistique appliquée est en prise directe avec la pratique. Elle mène ses programmes de recherche pour la pratique, sur la pratique et avec la pratique (Cameron, Frazer, Rampton \& Richardson, 1992: 22). Elle assure le transfert des connaissances acquises entre tous les acteurs engagés : la pratique objet d'étude, la science et l'ensemble de la société. Voilà définie la mission que se fixe la discipline.

Le présent ouvrage illustre la façon dont cette mission se traduit dans la recherche, le conseil et l'enseignement. Il prend comme exemple le Département de linguistique appliquée de l'Université des sciences appliquées de Zurich, l'une des rares structures de type département/faculté en Europe à accorder une large place à la linguistique appliquée, avec 16 chaires professorales et plus de $200 \mathrm{col}-$ laborateurs en linguistique appliquée. Le bénéfice de l'accès commun aux questions sociétales se manifeste dans la grande diversité des problèmes abordés et dans l'approche proactive des défis de notre temps. C'est cette valeur ajoutée que nous souhaitons mettre en lumière ici.

Le présent ouvrage exprime notre gratitude envers notre collègue Urs Willi, qui a dirigé et marqué de son empreinte, pendant trois décennies, le Département 
et l'école avant lui. Il donne la parole à des chercheurs et à des enseignants dont le travail façonne le Département de plus ou moins longue date. Il permet de mesurer le chemin parcouru et illustre, à l'aide d'exemples concrets, la façon dont les différents aspects de la discipline se recoupent et se complètent les uns les autres. Bien plus que la somme de ses parties, le Département contribue à la compréhension mutuelle dans la science, dans l'enseignement supérieur et dans les métiers des langues et de la communication, en particulier, mais aussi dans le quotidien, dans le monde professionnel et dans le grand public, en général.

Ulla Kleinberger, Daniel Perrin, Gianni De Nardi, Marlies Whitehouse et Cédric Luisier (traducteur), juin 2017

Cameron, D., Frazer, E., Rampton, B. \& Richardson, K. (1992). Researching language. Issues of power and method. London: Routledge.

Ruben, B. D. \& Gigliotti, R. A. (2017). Communication. Sine qua non of organizational leadership theory and practice. International Journal of Business Communication, 54(1), 12-30. 


\section{Mettere in pratica la linguistica applicata}

In aereo come all'ospedale, in economia come nei media occorre far sì che la comunicazione funzioni. Se siamo in grado di comunicare con successo, il mondo diventa più prevedibile e gestibile. Al contrario, gli equivoci, le incomprensioni e l'assenza di comunicazione rendono la collaborazione difficile o addirittura impossibile. Di conseguenza, non sorprende più di tanto che la comunicazione di successo sia un fattore chiave in un mondo sempre più connesso (p. e. Ruben \& Gigliotti, 2017). Ma come può la comunicazione avere successo? Come si può misurarne l'impatto? Chi deve fare che cosa, affinché il "com-municare" - ovvero la co-costruzione del senso - abbia esiti positivi?

La linguistica applicata si occupa di questioni riguardanti la comunicazione, la lingua, il comprendere e il comprendersi. Più precisamente, essa è alla ricerca di modelli linguistici all'interno di realtà sociali, di soluzioni a problemi sociali rilevanti nei quali la lingua riveste un ruolo cardine. In tale ambito rientra il fenomeno della comprensione reciproca all'interno dei gruppi e oltre i limiti sociali, ovvero tra vecchi e giovani, ricchi e poveri, profani ed esperti, nonché tra politica, società e scienza, senza dimenticare la comunicazione tra aree e culture linguistiche.

I risultati ottenuti nella nostra disciplina permettono di utilizzare la lingua in maniera efficiente ed efficace, e di organizzare la comunicazione di conseguenza. La linguistica applicata si orienta alla prassi. La ricerca in tale ambito viene condotta per la prassi, sulla prassi e con la prassi (Cameron, Frazer, Rampton \& Richardson, 1992: 22). Essa trasmette il sapere così acquisito a tutti i gruppi e attori coinvolti: alla prassi stessa che è stata suo oggetto di studio, alla scienza e all'intera società. Questo per quanto riguarda le aspirazioni della disciplina in sé.

In questo volume mostriamo cosa possa significare raggiungere questi obiettivi nella ricerca, nella consulenza e nell'insegnamento, prendendo ad esempio il Dipartimento di Linguistica applicata dell'Università di Scienze applicate di Zurigo. Si tratta di una delle poche istituzioni universitarie europee dedicate interamente alla linguistica applicata a livello di dipartimento/facoltà, con sedici professori e oltre duecento collaboratori e collaboratrici. Il valore aggiunto derivante dal comune approccio a problematiche sociali si esprime nella grande varietà e nell'elaborazione attiva delle attuali sfide linguistiche e comunicative nelle professioni e nella società. Proprio tale valore aggiunto intendiamo mettere in evidenza in questa sede.

Con questo volume esprimiamo un pubblico ringraziamento al nostro collega Urs Willi, che per oltre tre decenni ha diretto e plasmato il Dipartimento e la scuola che lo precedeva. Il libro raccoglie i contributi di ricercatori e docenti il 
cui lavoro, da più o meno tempo, dà lustro al Dipartimento. Esso invita a una visione d'insieme dei risultati conseguiti e mostra in esempi concreti come i diversi aspetti della disciplina interagiscano, si completino a vicenda e rendano il tutto maggiore della somma delle sue parti. Così si giunge ad un arricchimento della comprensione reciproca nella scienza e nel mondo accademico, nelle professioni linguistiche e della comunicazione e, in generale, nella vita quotidiana, nel mondo del lavoro e nella sfera pubblica.

Ulla Kleinberger, Daniel Perrin, Gianni De Nardi, Marlies Whitehouse e Angelo Ciampi, Marta Zampa (traduttori), giugno 2017

Cameron, D., Frazer, E., Rampton, B. \& Richardson, K. (1992). Researching language. Issues of power and method. London: Routledge.

Ruben, B. D. \& Gigliotti, R. A. (2017). Communication. Sine qua non of organizational leadership theory and practice. International Journal of Business Communication, 54(1), 12-30. 